Supplementary Information

\title{
Ligand Non-innocence in Nickel Porphyrins: Nickel Isobacteriochlorin Formation Under Hydrogen Evolution Conditions
}

\author{
Andrew G. Maher, Mengran Liu, and Daniel G. Nocera* \\ Department of Chemistry and Chemical Biology, 12 Oxford Street, Harvard University, Cambridge, MA \\ 02138-2902 U.S.A. \\ *dnocera@fas.harvard.edu
}


Figure S1. Absorption spectrum of [Ni-Phl]- $\quad$ S3

Figure S2. ${ }^{1} \mathrm{H}$ NMR of [Ni-Phl] ${ }^{-} \quad$ S4

Figure S3. HR-MS of [Ni-Phl]-

Figure S4. Absorption spectra of [Ni-Phl]-following addition of tosic acid S6

Figure S5. Absorption spectra during bulk electrolysis of Ni-P and tosic acid $\quad$ S7

Figure S6. ${ }^{1} \mathrm{H}$ NMR of Ni-iBC $\quad$ S8

$\begin{array}{ll}\text { Figure S7. HR-MS of Ni-iBC } & \text { S9 }\end{array}$

Figure S8. Absorption spectrum of Ni-iBC following alumina chromatography $\quad$ S10

Figure S9. Scan rate dependence of $\mathbf{N i - i B C}{ }^{0 /-}$ wave and trumpet plot $\quad$ S11

Figure S10. Spectroelectrochemistry of [Ni-iBC]- oxidation to Ni-iBC $\quad$ S12

Figure S11. CVs of tosic acid without Ni complexes present $\quad$ S13

$\begin{array}{ll}\text { Figure S12. Faradaic yield measurements } & \text { S14 }\end{array}$

Figure S13. Absorption spectrum after bulk electrolysis of Ni-iBC and tosic acid $\quad$ S15

Figure S14. Rinse test of Ni-P with tosic acid $\quad$ S16

$\begin{array}{ll}\text { Figure S15. Rinse test of Ni-iBC with tosic acid } & \text { S17 }\end{array}$

Figure S16. CVs of Ni-iBC with trifluoroacetic acid $\quad$ S18

Figure S17. Rinse test of Ni-iBC with trifluoroacetic acid $\quad$ S19

Figure S18. $\mathrm{CVs}$ of $\mathrm{Ni}\left(\mathrm{ClO}_{4}\right)_{2} \bullet 6 \mathrm{H}_{2} \mathrm{O}$ with tosic acid $\quad \mathrm{S} 20$

Figure S19. Rinse test of $\mathrm{Ni}\left(\mathrm{ClO}_{4}\right)_{2} \bullet 6 \mathrm{H}_{2} \mathrm{O}$ with tosic acid $\quad \mathrm{S} 21$

Figure S20. Overlay of rinse test $\mathrm{CVs}$ of $\mathrm{Ni}-\mathrm{iBC}$ and $\mathrm{Ni}\left(\mathrm{ClO}_{4}\right)_{2} \bullet 6 \mathrm{H}_{2} \mathrm{O}$ with tosic acid $\quad \mathrm{S} 22$

$\begin{array}{ll}\text { Figure S21. CV of Zn-P } & \text { S23 }\end{array}$ 


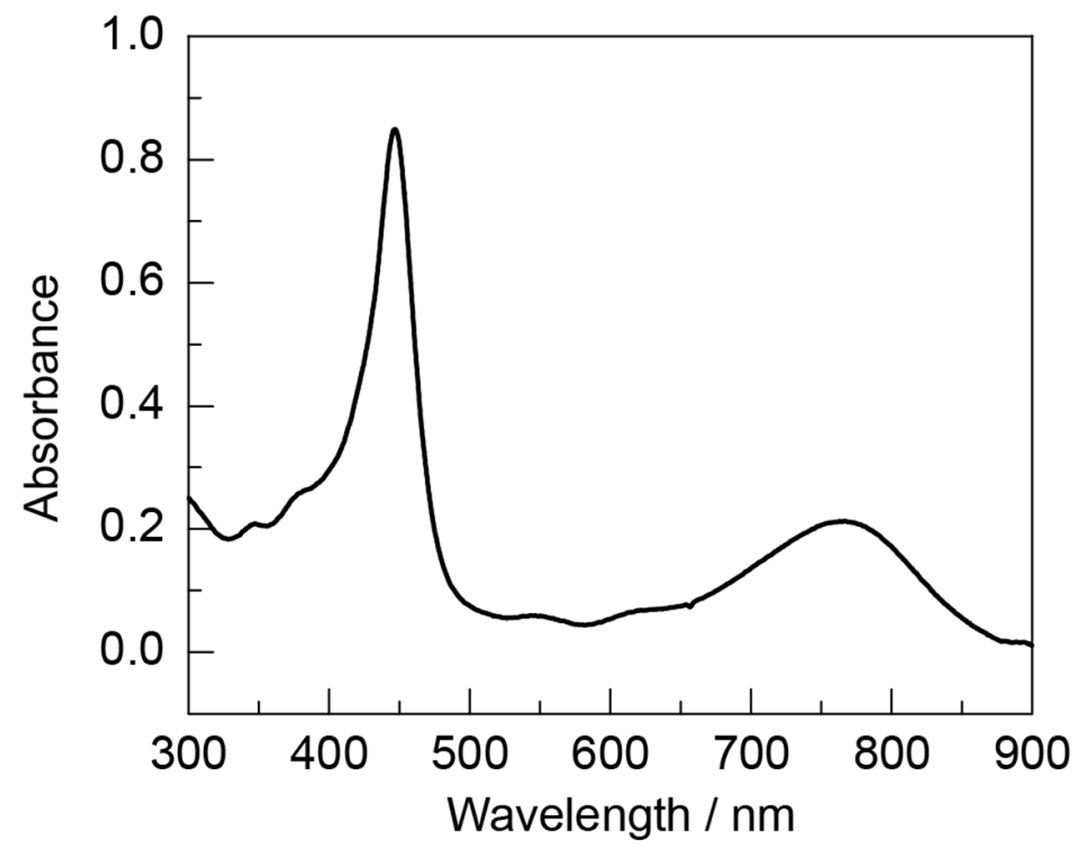

Figure S1. UV-vis absorption spectrum of [Ni-Phl] ${ }^{-}$in $\mathrm{CH}_{3} \mathrm{CN}$. 


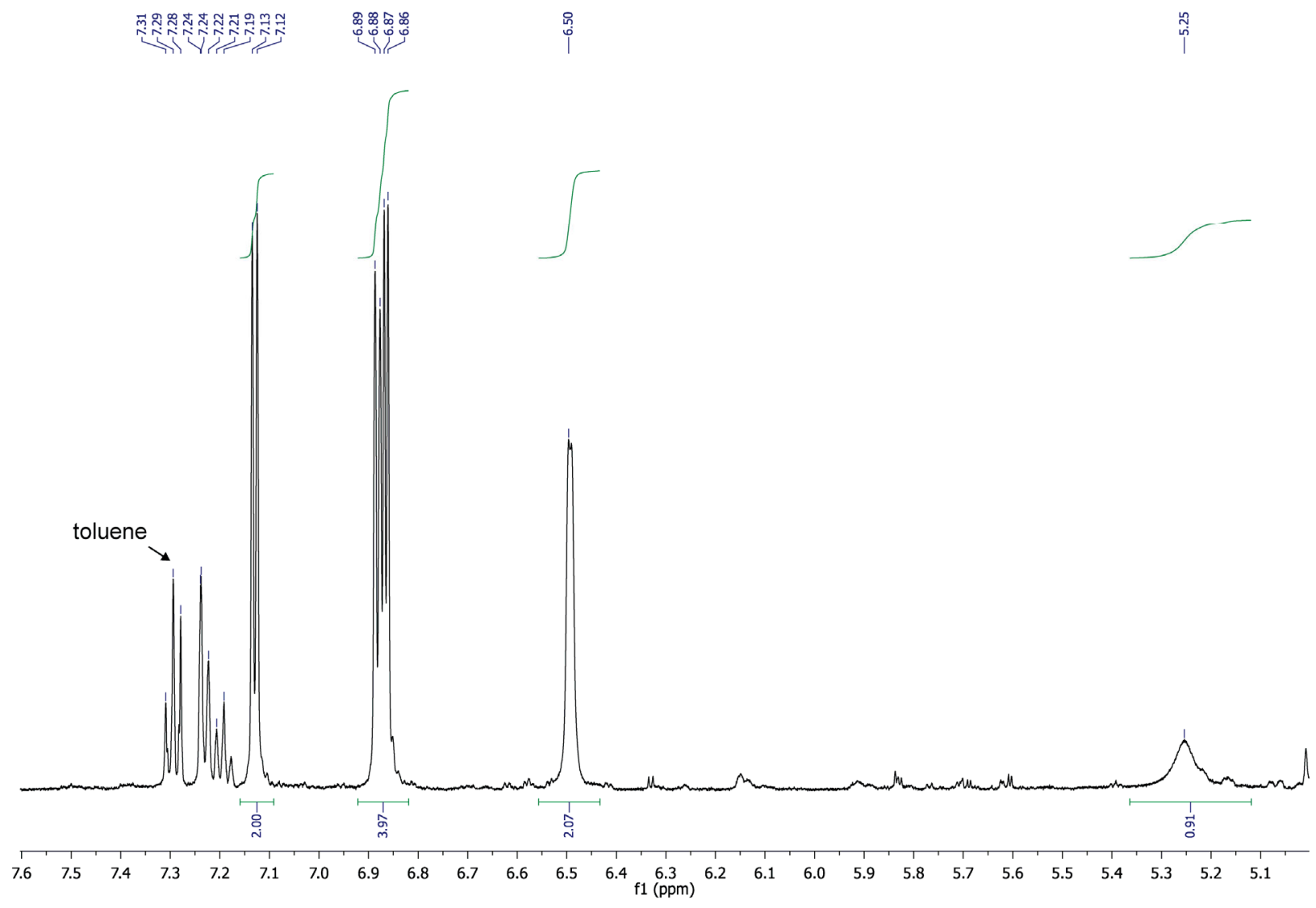

Figure S2. ${ }^{1} \mathrm{H}$ NMR spectrum of [Ni-Phl]- in $\mathrm{CD}_{3} \mathrm{CN}$ at room temperature. 

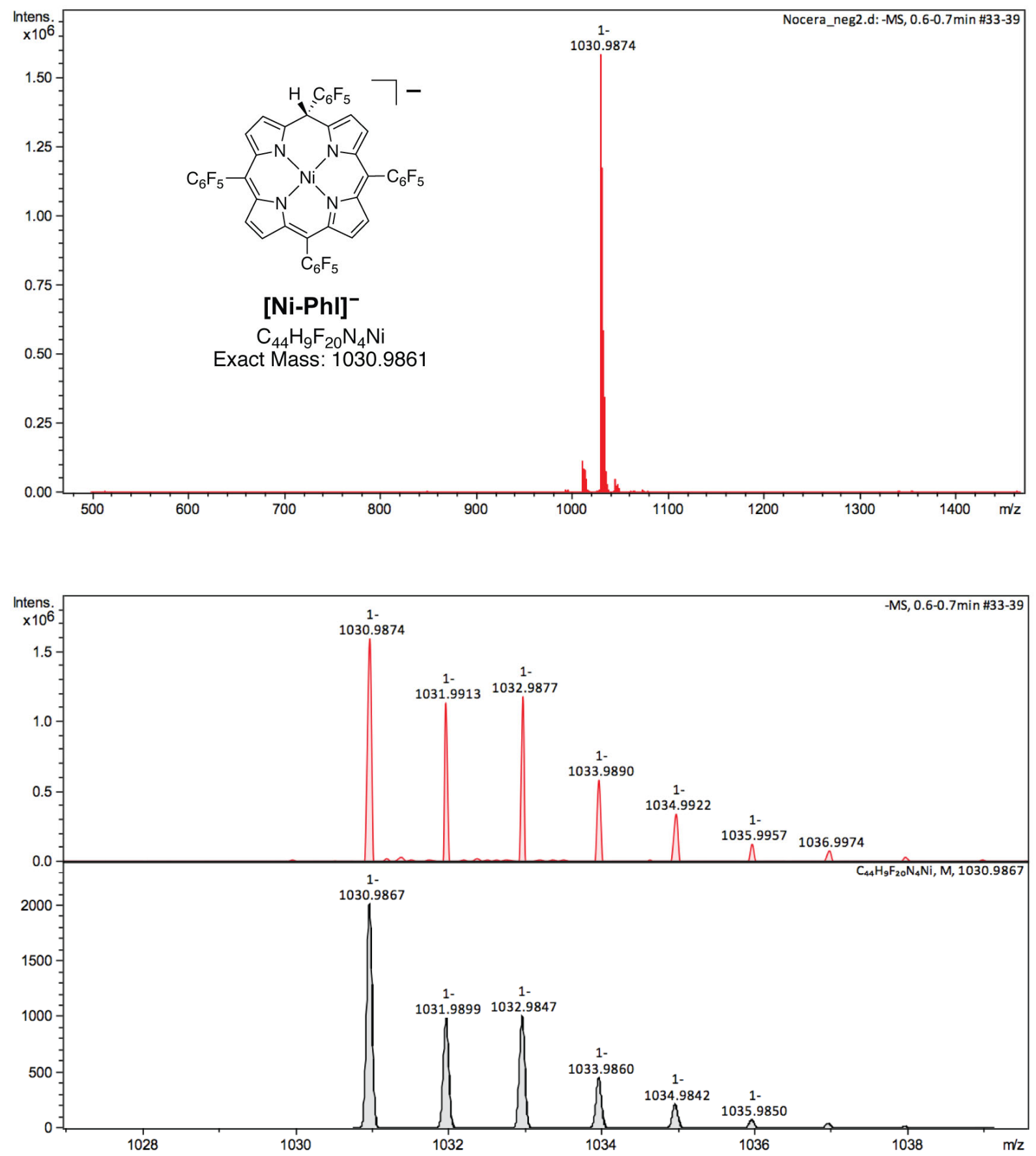

Figure S3. High-resolution MS of [Ni-Phl]- using negative ion mode. 


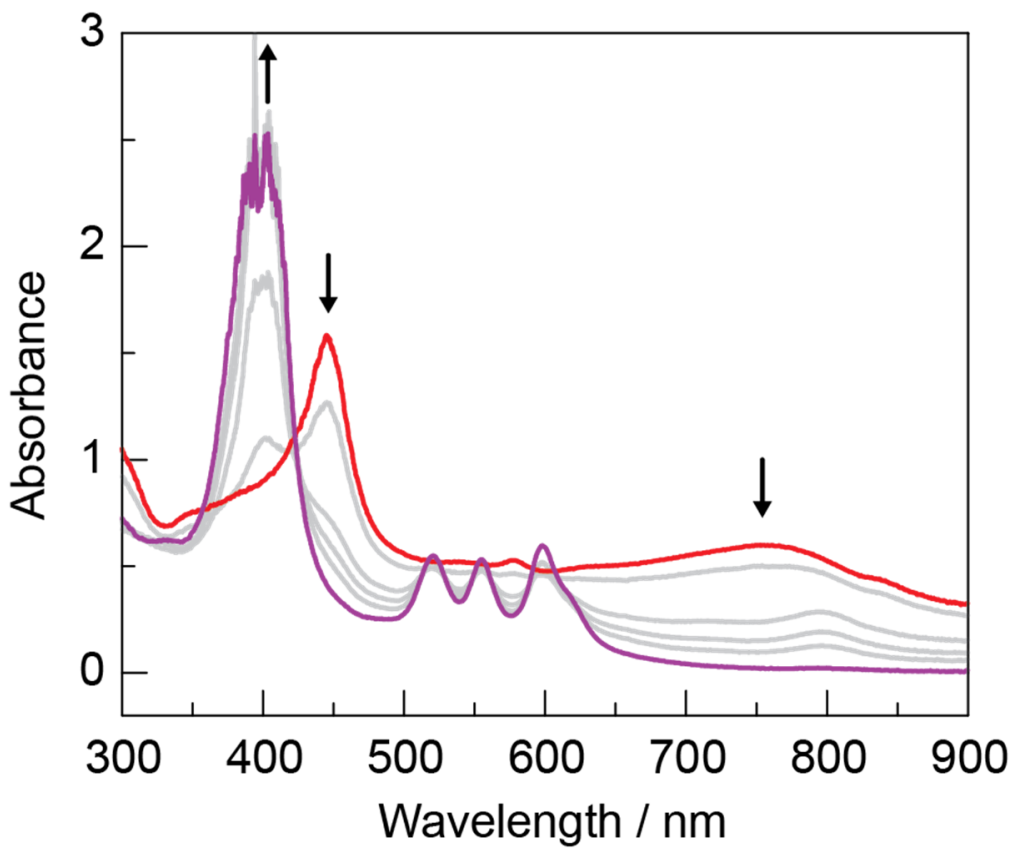

Figure S4. UV-vis absorption spectral change following addition of excess tosic acid to [Ni-Phl]- in $\mathrm{CH}_{3} \mathrm{CN}$. Initial spectrum: 一, red; final spectrum: -, purple. Spectra were acquired over a period of $20 \mathrm{~s}$. 


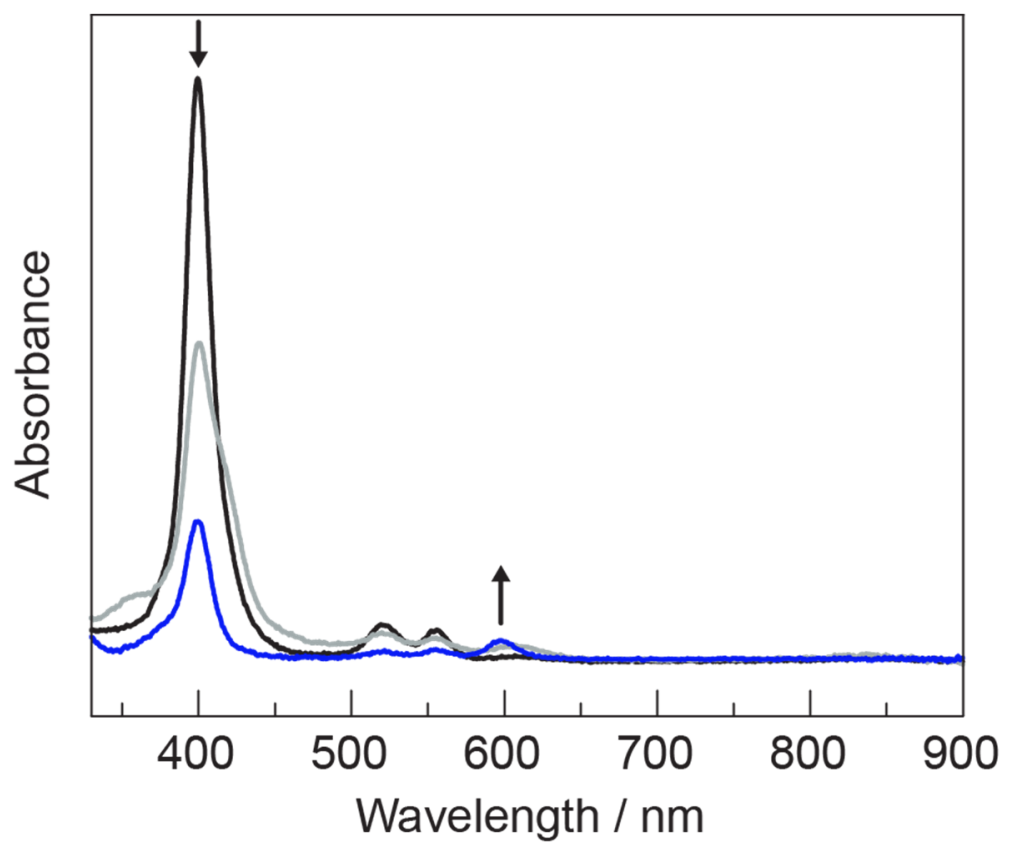

Figure S5. UV-vis absorption spectra of before (-, black) and after ( - , blue) $30 \mathrm{~min}$ of controlled-potential bulk electrolysis of $\mathbf{N i}-\mathbf{P}$ at a potential of $-1.4 \mathrm{~V}$ vs. $\mathrm{Fc}^{+} / \mathrm{Fc}$ in $\mathrm{CH}_{3} \mathrm{CN}(0.1$ $\mathrm{M} \mathrm{TBAPF}_{6}$ ) in the presence of 4.4 equiv of tosic acid. Working electrode: glassy carbon crucible; counter electrode: platinum wire. The sharp Soret band signal near $400 \mathrm{~nm}$ is indicative of a small amount of remaining porphyrin or chlorin signal due to incomplete conversion to Ni-iBC. 


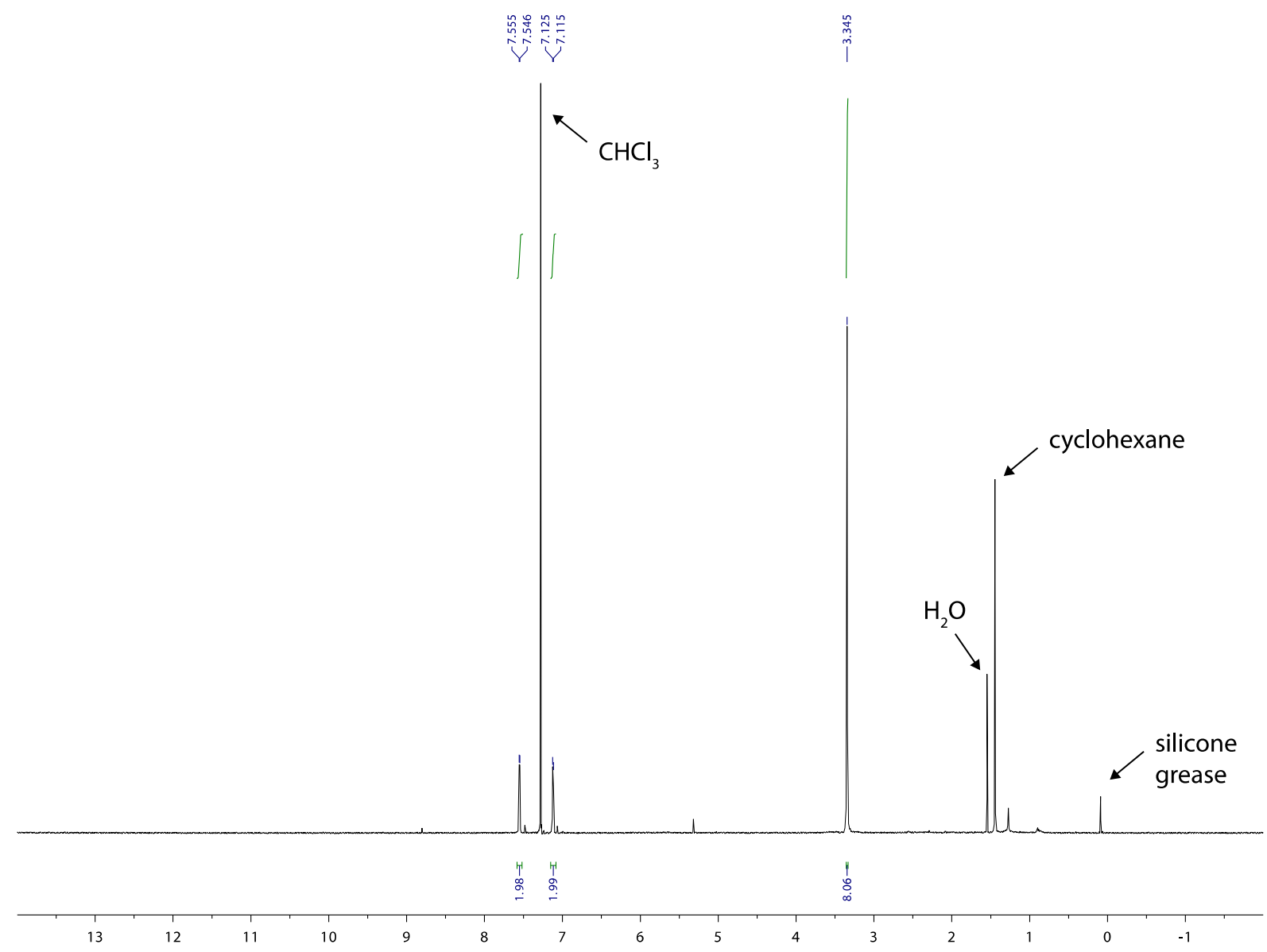

Figure S6. ${ }^{1} \mathrm{H} \mathrm{NMR}$ of $\mathrm{Ni}-\mathrm{iBC}$ in $\mathrm{CDCl}_{3}$ at room temperature. 

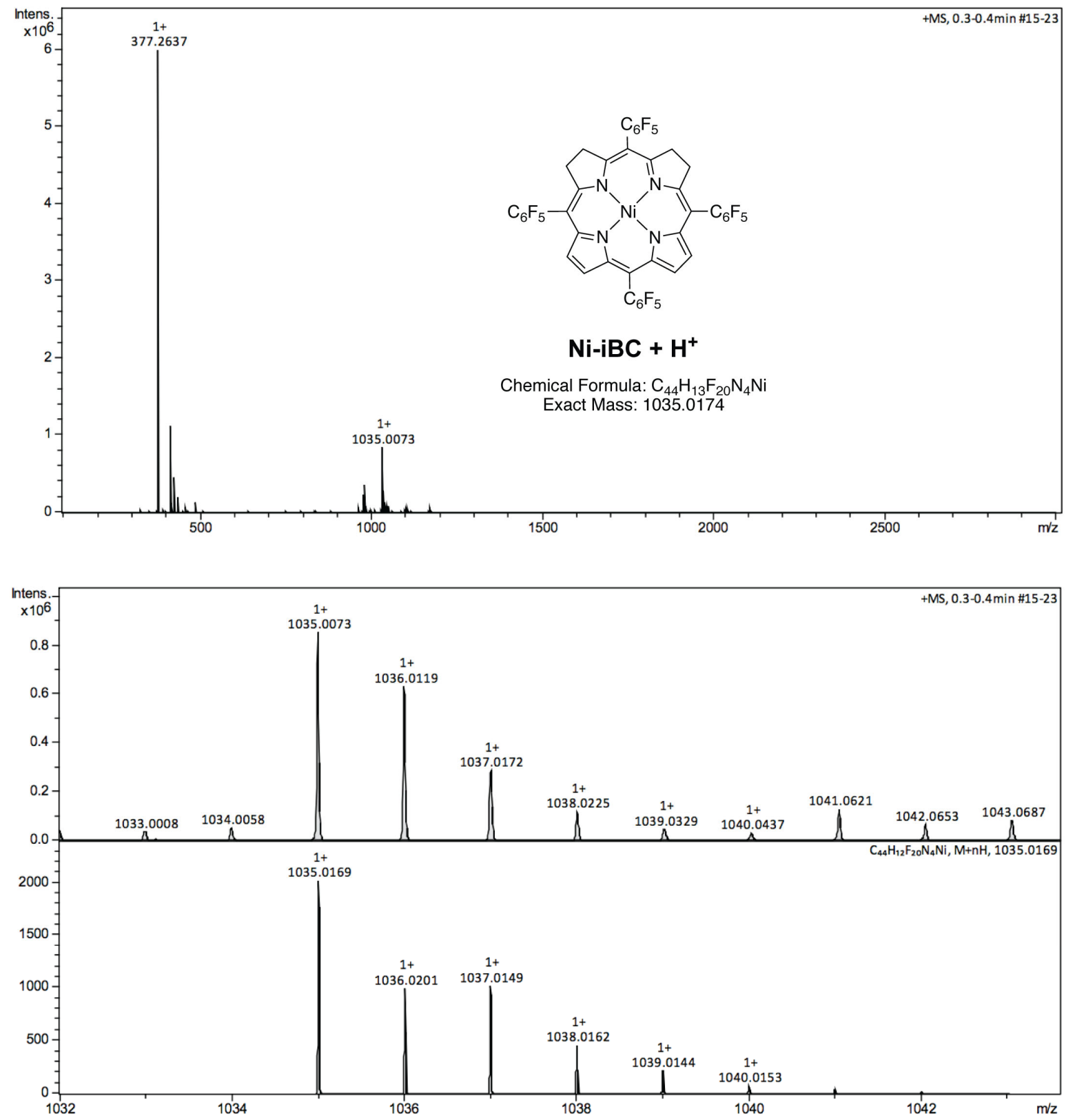

Figure S7. High-resolution MS of Ni-iBC using positive ion mode 


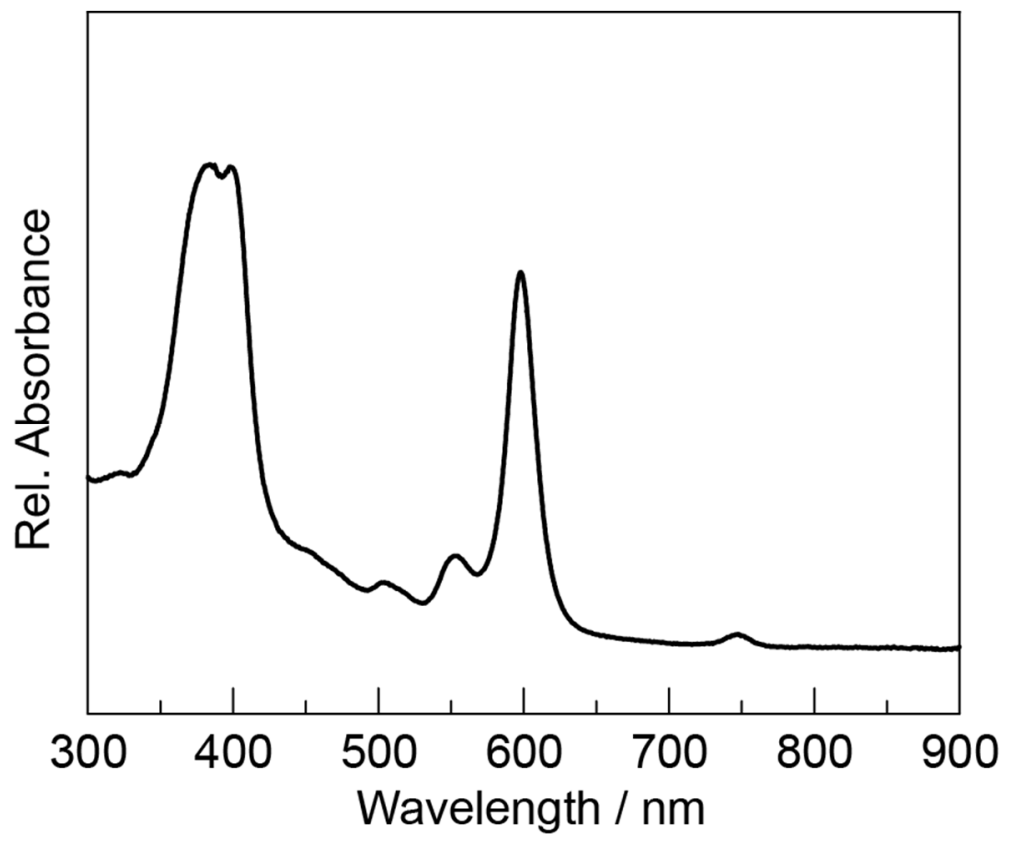

Figure S8. UV-vis absorption spectrum of isolated $\mathbf{N i - i B C}$ in $\mathrm{CH}_{3} \mathrm{CN}$ following alumina column chromatography. 

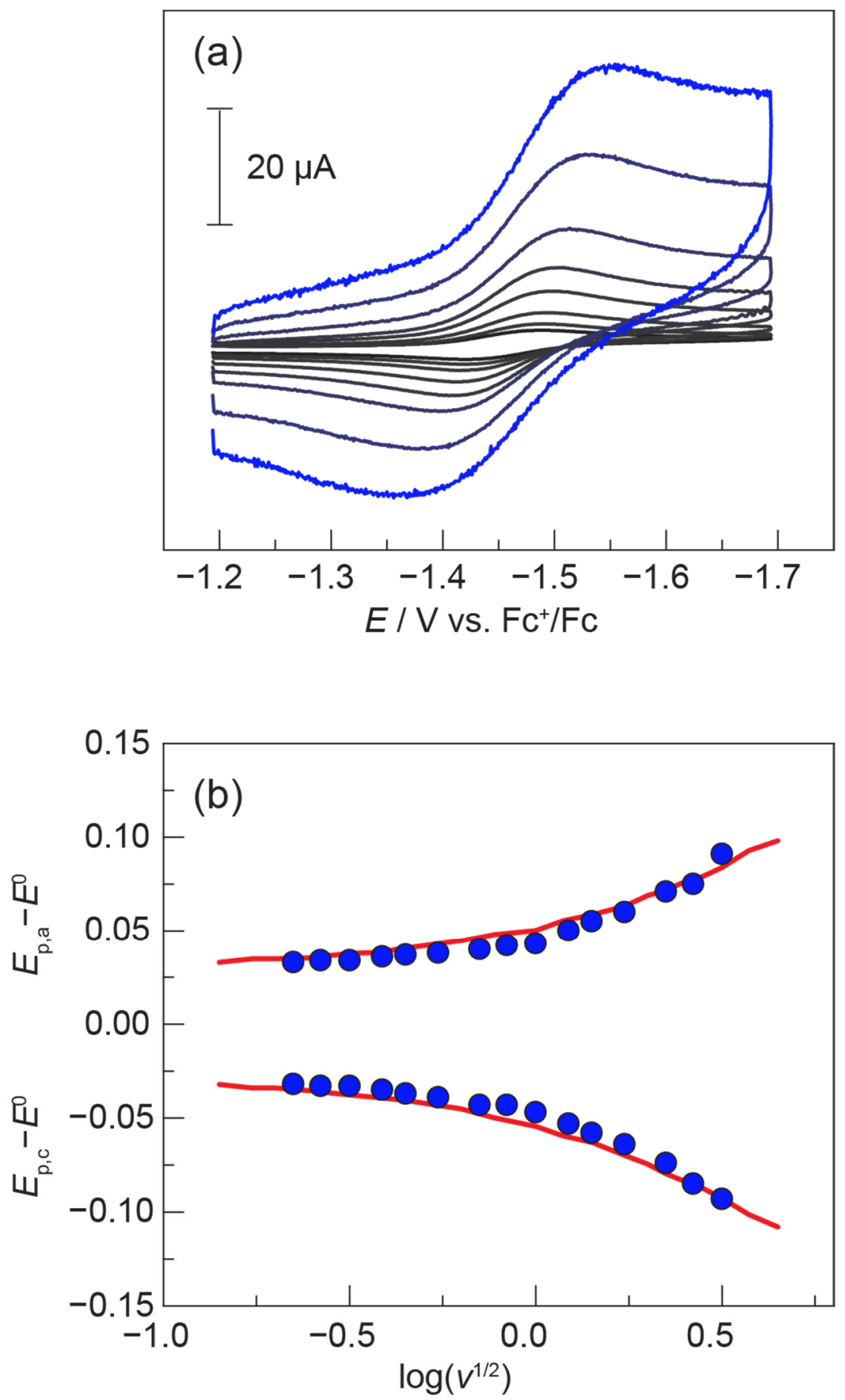

Figure S9. (a) $\mathrm{CVs}$ of $0.32 \mathrm{mM} \mathrm{Ni-iBC}$ in $\mathrm{CH}_{3} \mathrm{CN}\left(0.1 \mathrm{M} \mathrm{TBAPF}_{6}\right)$ at scan rates $(v)$ ranging from $0.05 \mathrm{~V} \mathrm{~s}^{-1}$ (一, black) to $10 \mathrm{~V} \mathrm{~s}^{-1}$ (一, blue). (b) Cathodic and anodic peak potential shifts at different scan rates $(\bullet$, blue dots) along with the working curve $(-$, red) that furnishes a standard heterogeneous rate constant for electron transfer of $k \mathrm{~s}^{\mathrm{ap}}=0.014 \mathrm{~cm} \mathrm{~s}^{-1}$. 


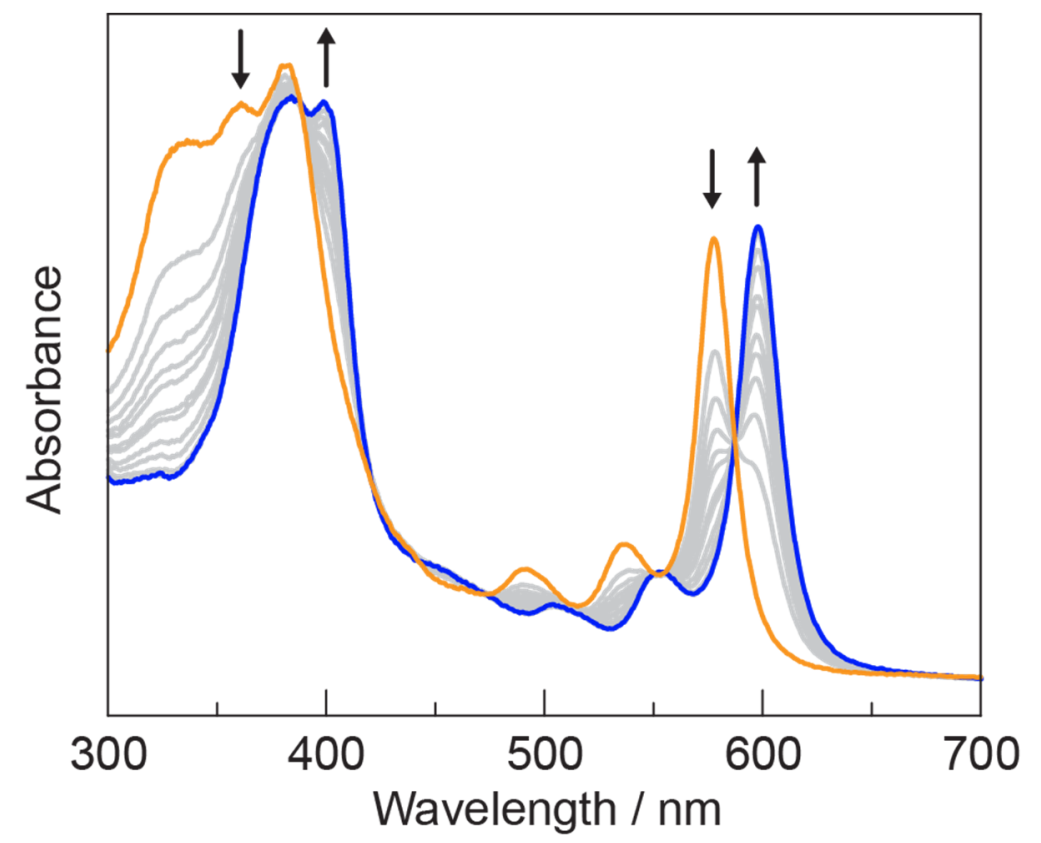

Figure S10. Thin-layer UV-vis spectroelectrochemistry of Ni-iBC showing the oxidation of [Ni-iBC] $^{-}\left(-\right.$, orange) back to $\mathbf{N i}^{-i B C}{ }^{0}(-$, blue). The spectra shown were acquired while the potential was held at $-0.1 \mathrm{~V}$ vs. $\mathrm{Fc}^{+} / \mathrm{Fc}$ for $120 \mathrm{~s}$ after a potential of $-1.6 \mathrm{Vvs}$. $\mathrm{Fc}^{+} / \mathrm{Fc}$ had been held for $200 \mathrm{~s}$. 


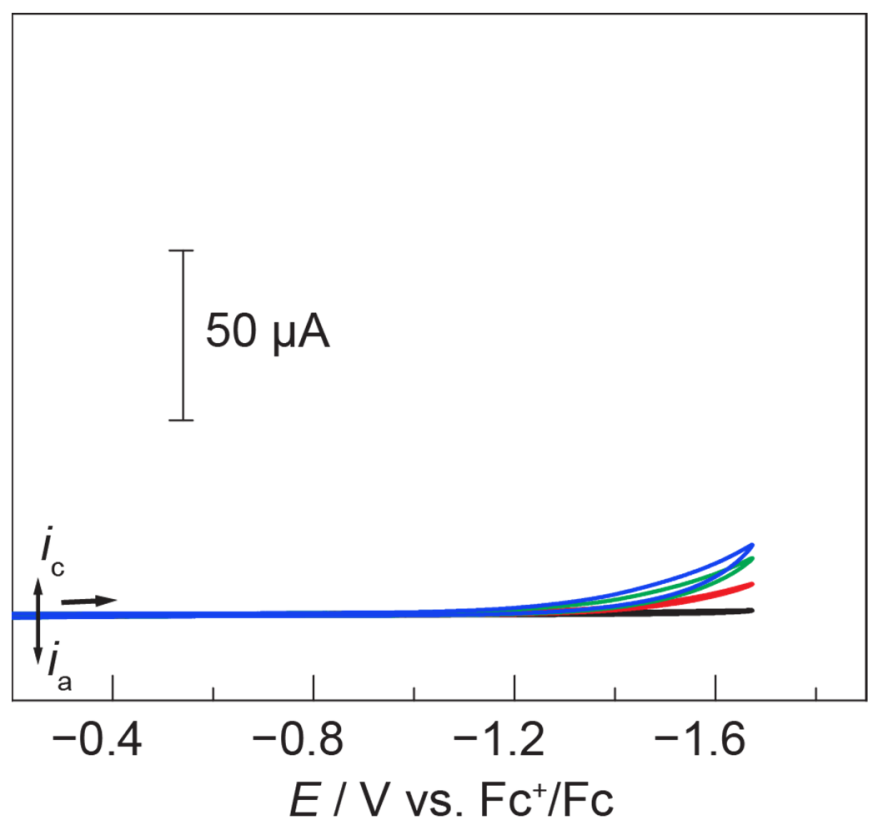

Figure S11. $\mathrm{CVs}$ in $\mathrm{CH}_{3} \mathrm{CN}\left(0.1 \mathrm{M} \mathrm{TBAPF}_{6}\right)$ at a scan rate of $0.1 \mathrm{~V} \mathrm{~s}^{-1}$ using a glassy carbon working electrode in the presence of only tosic acid at the following concentrations: 0 ( - , black), 2.0 ( - , red), 5.0 (-, green), and $10.0 \mathrm{mM}(-$, blue). 

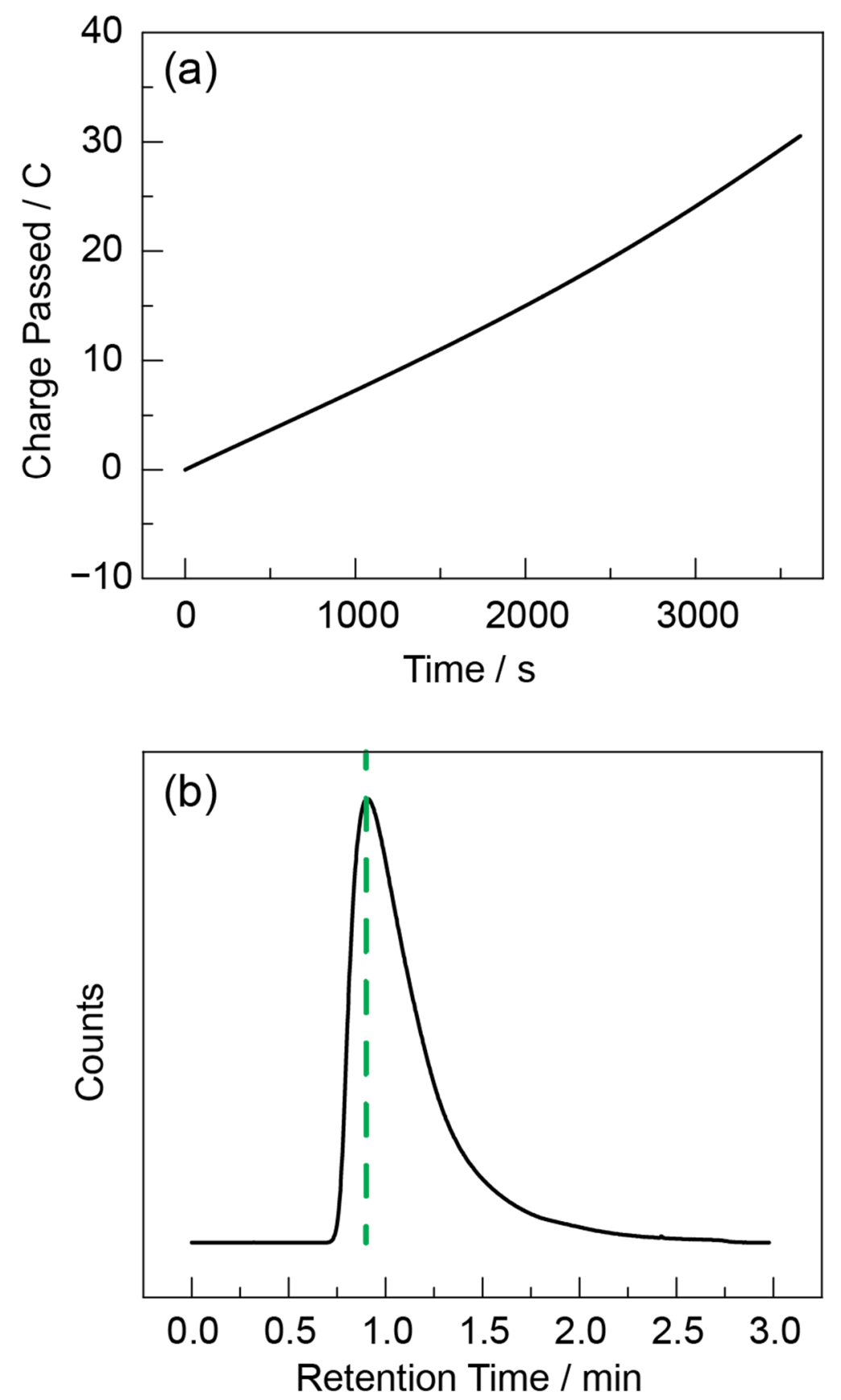

Figure S12. (a) Charge passed during bulk electrolysis of Ni-iBC in the presence of $30 \mathrm{mM}$ tosic acid in $\mathrm{CH}_{3} \mathrm{CN}\left(0.1 \mathrm{M} \mathrm{TBAPF}_{6}\right)$ at an applied potential of $-1.6 \mathrm{~V}$ vs. $\mathrm{Fc}^{+} / \mathrm{Fc}$. (b) GC of the headspace following the bulk electrolysis ( - , black). The retention time for pure $\mathrm{H}_{2}$ gas is indicated (--, dashed green). 


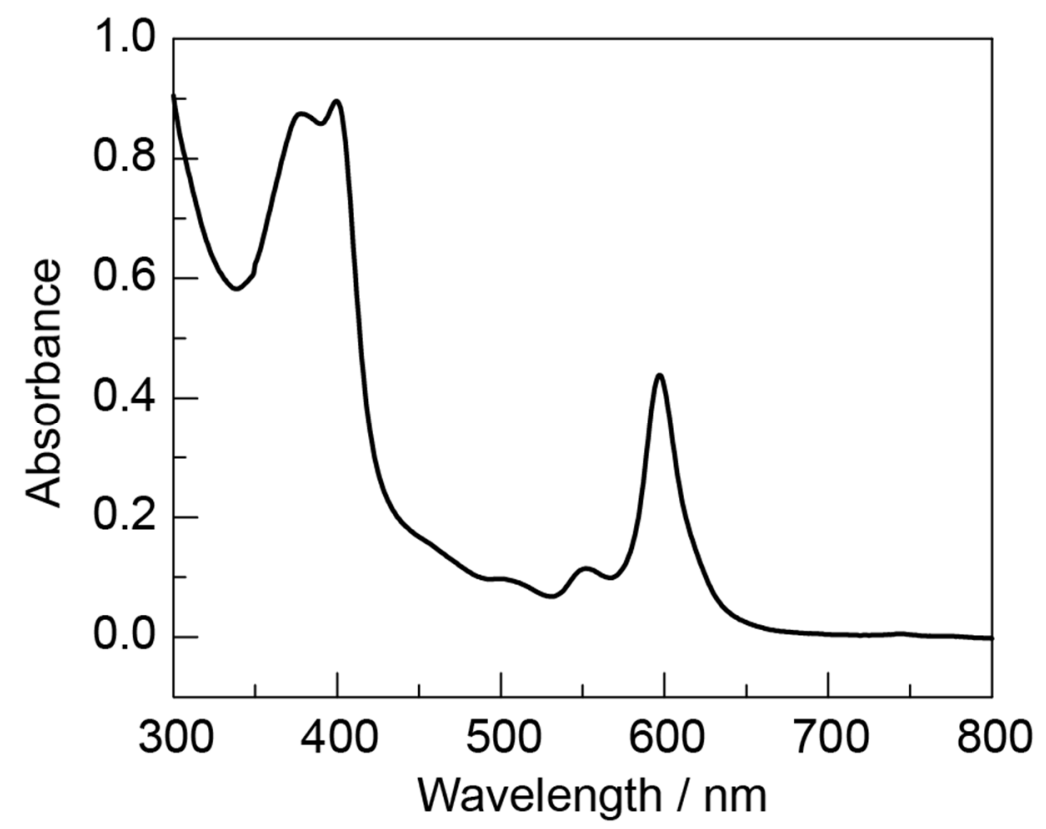

Figure S13. UV-vis absorption spectrum of the resulting solution following bulk electrolysis of $\mathrm{Ni}-\mathrm{iBC}$ in $\mathrm{CH}_{3} \mathrm{CN}\left(0.1 \mathrm{M} \mathrm{TBAPF}_{6}\right)$ in the presence of $30 \mathrm{mM}$ tosic acid. The solution was diluted by a factor of 5 in the cuvette used for the absorption spectrum. 


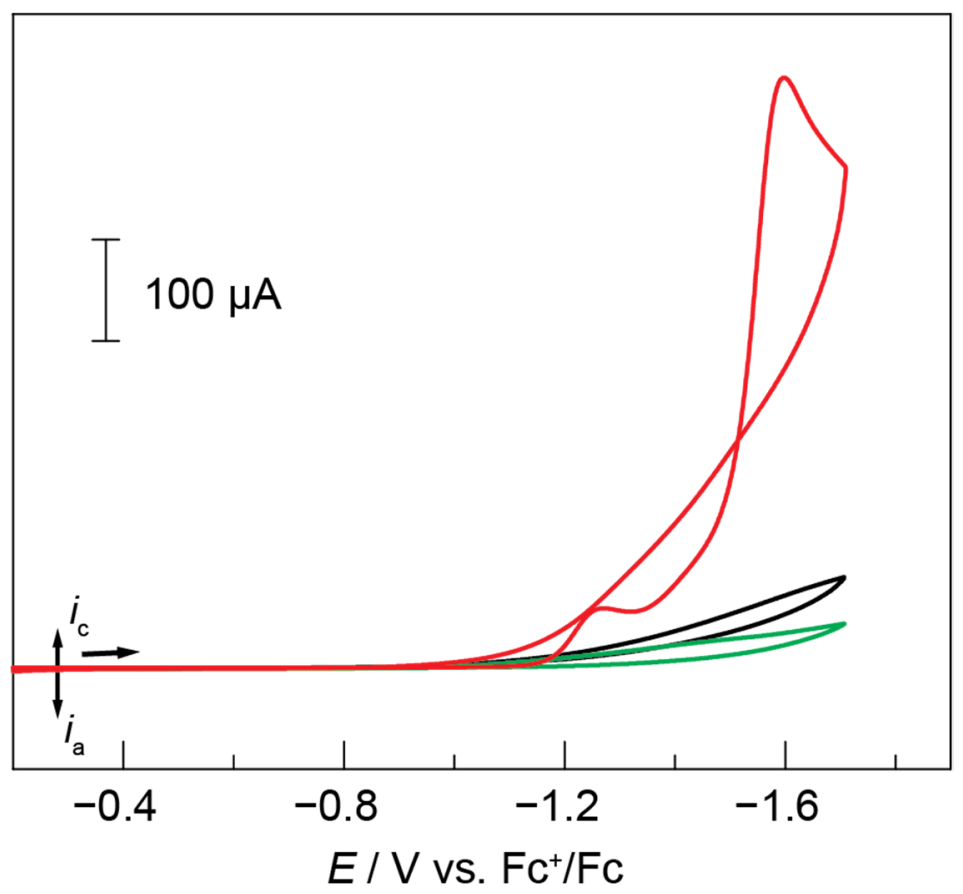

Figure S14. Red trace (-): CV of $0.71 \mathrm{mM} \mathrm{Ni-P}$ in $\mathrm{CH}_{3} \mathrm{CN}\left(0.1 \mathrm{M} \mathrm{TBAPF}_{6}\right)$ at a scan rate of $0.1 \mathrm{~V} \mathrm{~s}^{-1}$ using a glassy carbon working electrode $(3.0 \mathrm{~mm}$ diameter) in the presence of 50 $\mathrm{mM}$ tosic acid. Black trace (-): CV taken using the same working electrode in fresh $\mathrm{CH}_{3} \mathrm{CN}$ /electrolyte solution containing only $50 \mathrm{mM}$ tosic acid after a potential of $-1.7 \mathrm{~V}$ vs. $\mathrm{FC}^{+} / \mathrm{Fc}$ was held in the solution containing $0.71 \mathrm{mM}$ Ni-P and $50 \mathrm{mM}$ tosic acid for $2 \mathrm{~min}$. Green trace (-): $\mathrm{CV}$ of a freshly polished glassy carbon electrode in the $\mathrm{CH}_{3} \mathrm{CN}$ /electrolyte solution containing only $50 \mathrm{mM}$ tosic acid (no Ni-P in solution). 


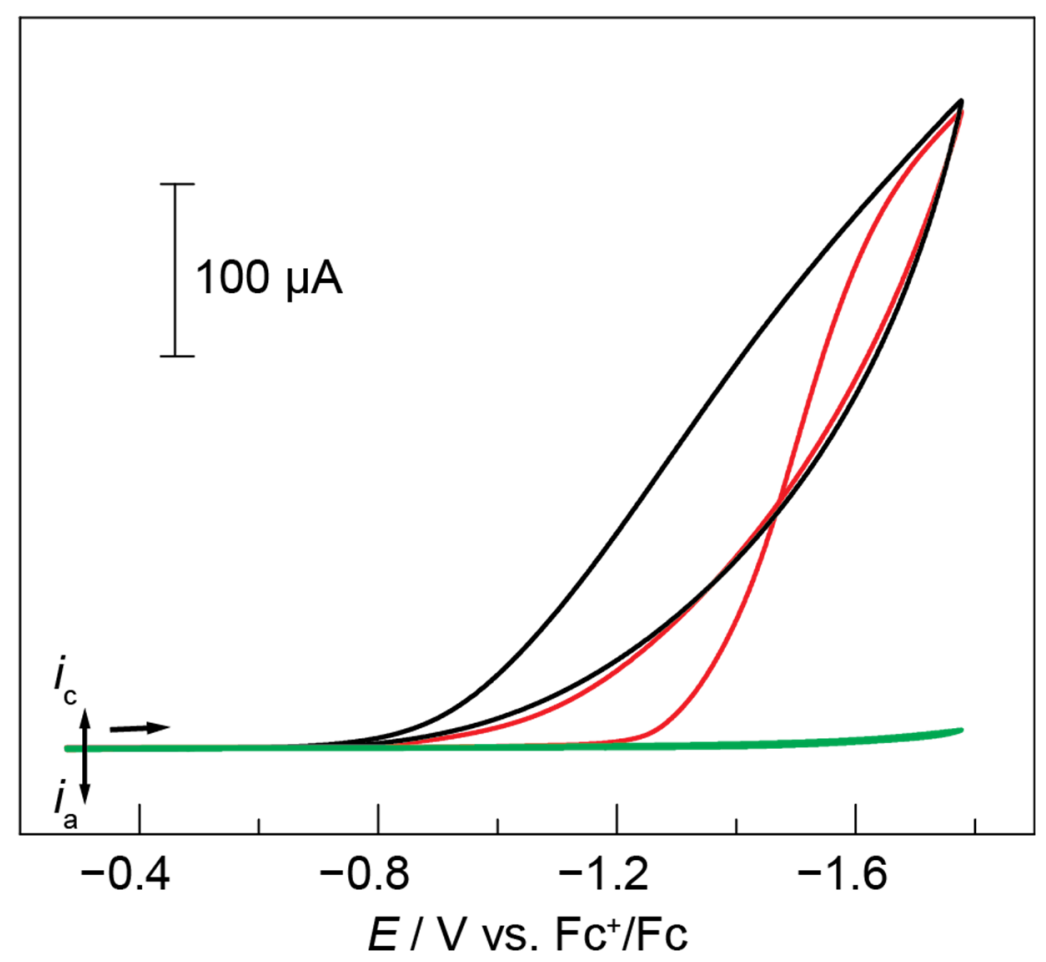

Figure S15. Red trace (-): CV of $1 \mathrm{mM} \mathrm{Ni-iBC}$ in $\mathrm{CH}_{3} \mathrm{CN}\left(0.1 \mathrm{M} \mathrm{TBAPF}_{6}\right)$ at a scan rate of 0.1 $\mathrm{V} \mathrm{s}^{-1}$ using a glassy carbon working electrode $(3.0 \mathrm{~mm}$ diameter $)$ in the presence of $50 \mathrm{mM}$ tosic acid. Black trace (-): CV taken using the same working electrode in fresh $\mathrm{CH}_{3} \mathrm{CN} /$ electrolyte solution containing only $50 \mathrm{mM}$ tosic acid after a potential of $-1.7 \mathrm{~V}$ vs. $\mathrm{Fc}^{+} / \mathrm{Fc}$ was held in the solution containing $1 \mathrm{mM} \mathrm{Ni-iBC}$ and $50 \mathrm{mM}$ tosic acid for $2 \mathrm{~min}$. Green trace (-): CV of a freshly polished glassy carbon electrode in the $\mathrm{CH}_{3} \mathrm{CN} /$ electrolyte solution containing only $50 \mathrm{mM}$ tosic acid (no Ni-iBC in solution). 

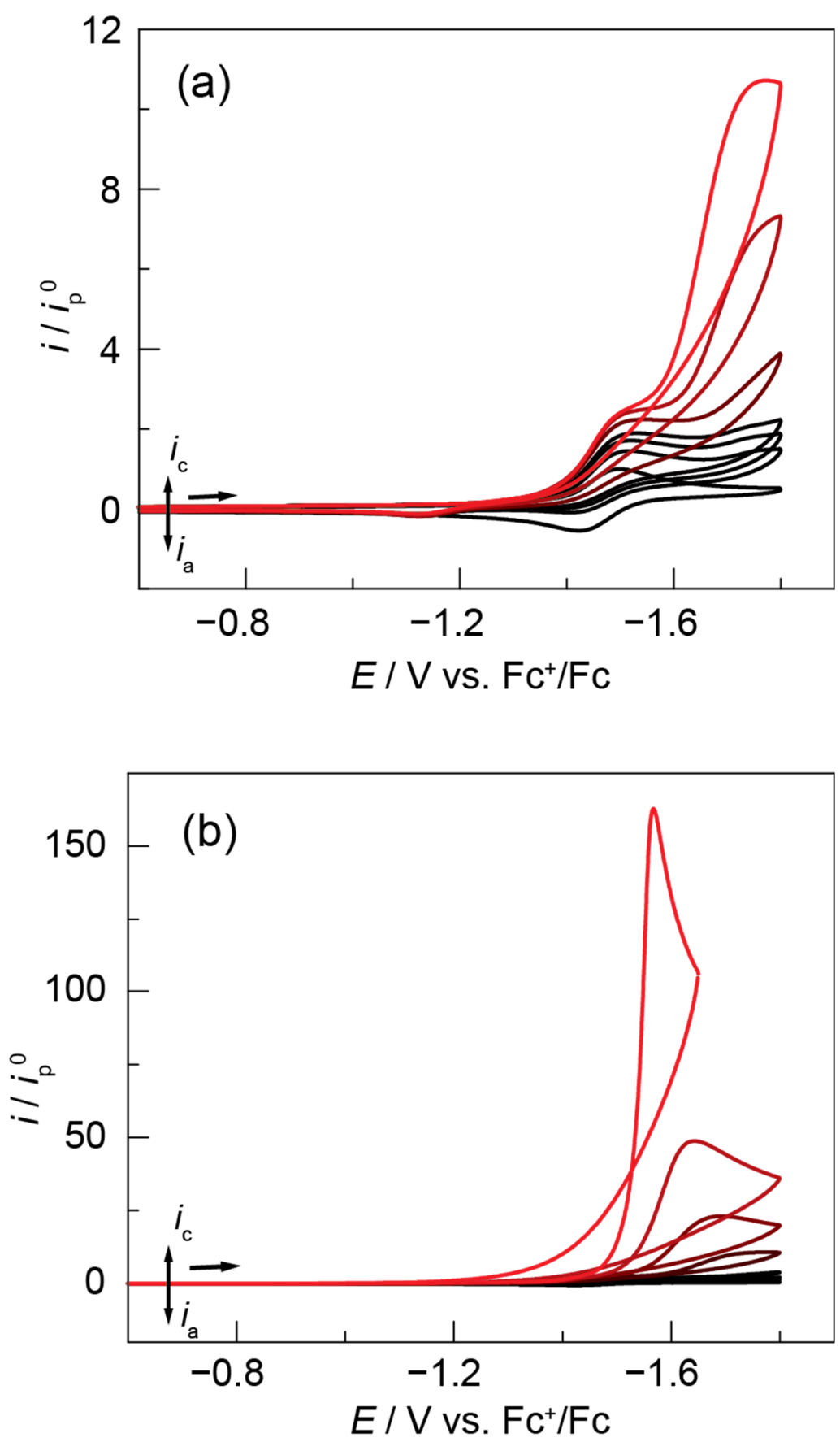

Figure S16. CVs of $\mathbf{N i - i B C}(0.30 \mathrm{mM})$ in $\mathrm{CH}_{3} \mathrm{CN}\left(0.1 \mathrm{M} \mathrm{TBAPF}_{6}\right)$ at a scan rate of $0.1 \mathrm{~V} \mathrm{~s}^{-1}$ (glassy carbon working electrode) in the presence of trifluoroacetic acid at the following concentrations (from black to red): (a) 0, 0.5, 0.75, 1.0, 2.0, 3.5, and 5.0 mM; (b) 0, 0.5, 1.0, $2.0,5.0,10.0,20.0$, and $50.0 \mathrm{mM}$. 


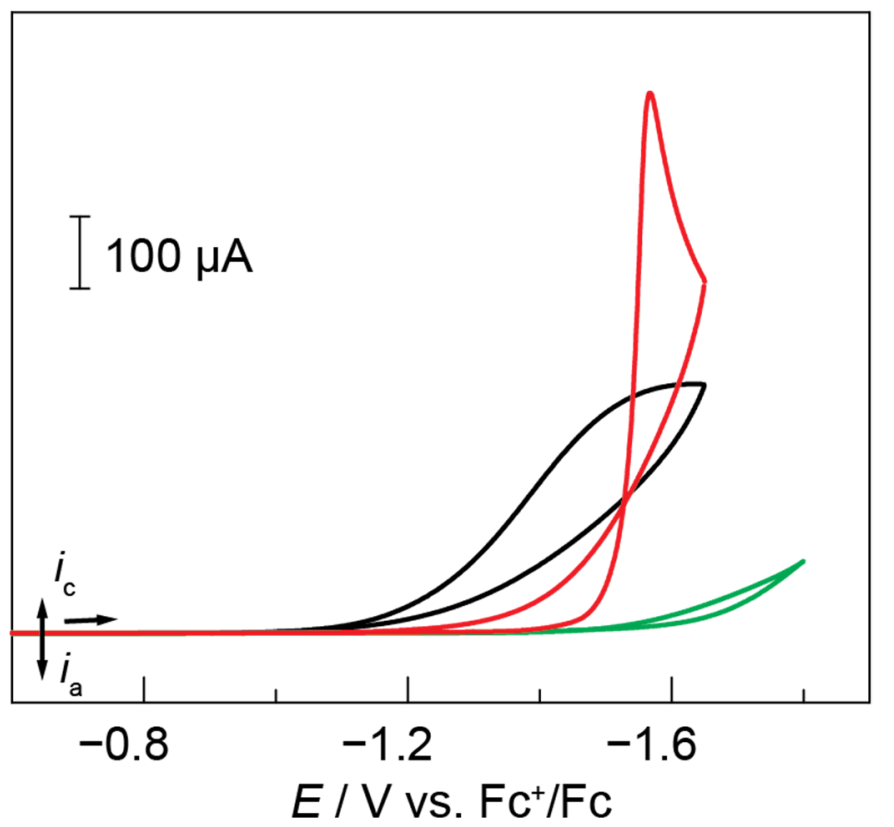

Figure S17. Red trace (-): $\mathrm{CV}$ of $0.30 \mathrm{mM} \mathrm{Ni-iBC}$ in $\mathrm{CH}_{3} \mathrm{CN}\left(0.1 \mathrm{M} \mathrm{TBAPF}_{6}\right)$ at a scan rate of $0.1 \mathrm{~V} \mathrm{~s}^{-1}$ using a glassy carbon working electrode $(3.0 \mathrm{~mm}$ diameter) in the presence of 50 $\mathrm{mM}$ trifluoroacetic acid. Black trace (-): CV taken using the same working electrode in fresh $\mathrm{CH}_{3} \mathrm{CN}$ /electrolyte solution containing only $50 \mathrm{mM}$ trifluoroacetic acid after a potential of $-1.7 \mathrm{~V}$ vs. $\mathrm{Fc}^{+} / \mathrm{Fc}$ was held in the solution containing $0.30 \mathrm{mM} \mathrm{Ni}$-iBC and $50 \mathrm{mM}$ trifluoroacetic acid for $2 \mathrm{~min}$. Green trace (-): CV of a freshly polished glassy carbon electrode in the $\mathrm{CH}_{3} \mathrm{CN} /$ electrolyte solution containing only $50 \mathrm{mM}$ tosic acid (no Ni-iBC in solution). 


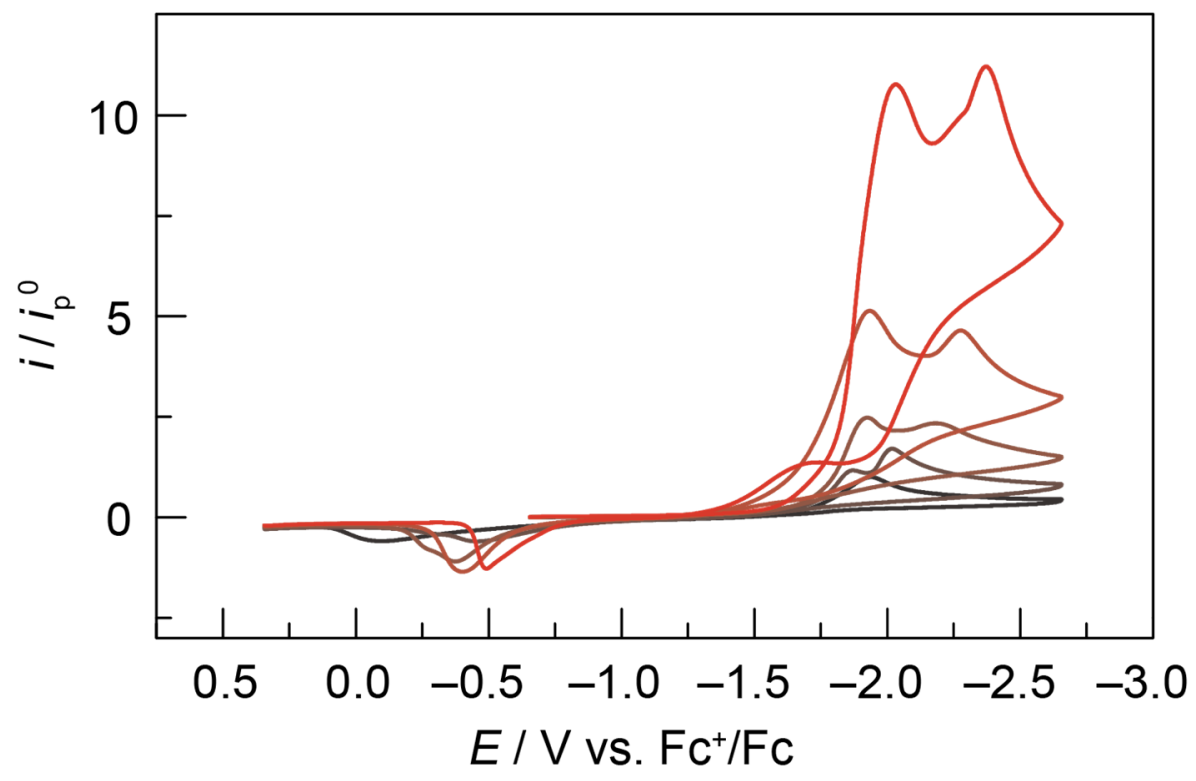

Figure S18. $\mathrm{CVs}$ of $\mathrm{Ni}\left(\mathrm{ClO}_{4}\right)_{2} \cdot 6 \mathrm{H}_{2} \mathrm{O}(0.5 \mathrm{mM})$ in $\mathrm{CH}_{3} \mathrm{CN}\left(0.1 \mathrm{M} \mathrm{TBAPF}_{6}\right)$ at a scan rate of $0.1 \mathrm{~V}$ $\mathrm{s}^{-1}$ (glassy carbon working electrode) in the presence of tosic acid at the following concentrations (from black to red): 0,1.0, 5.0, 10.0, and $20.0 \mathrm{mM}$. 


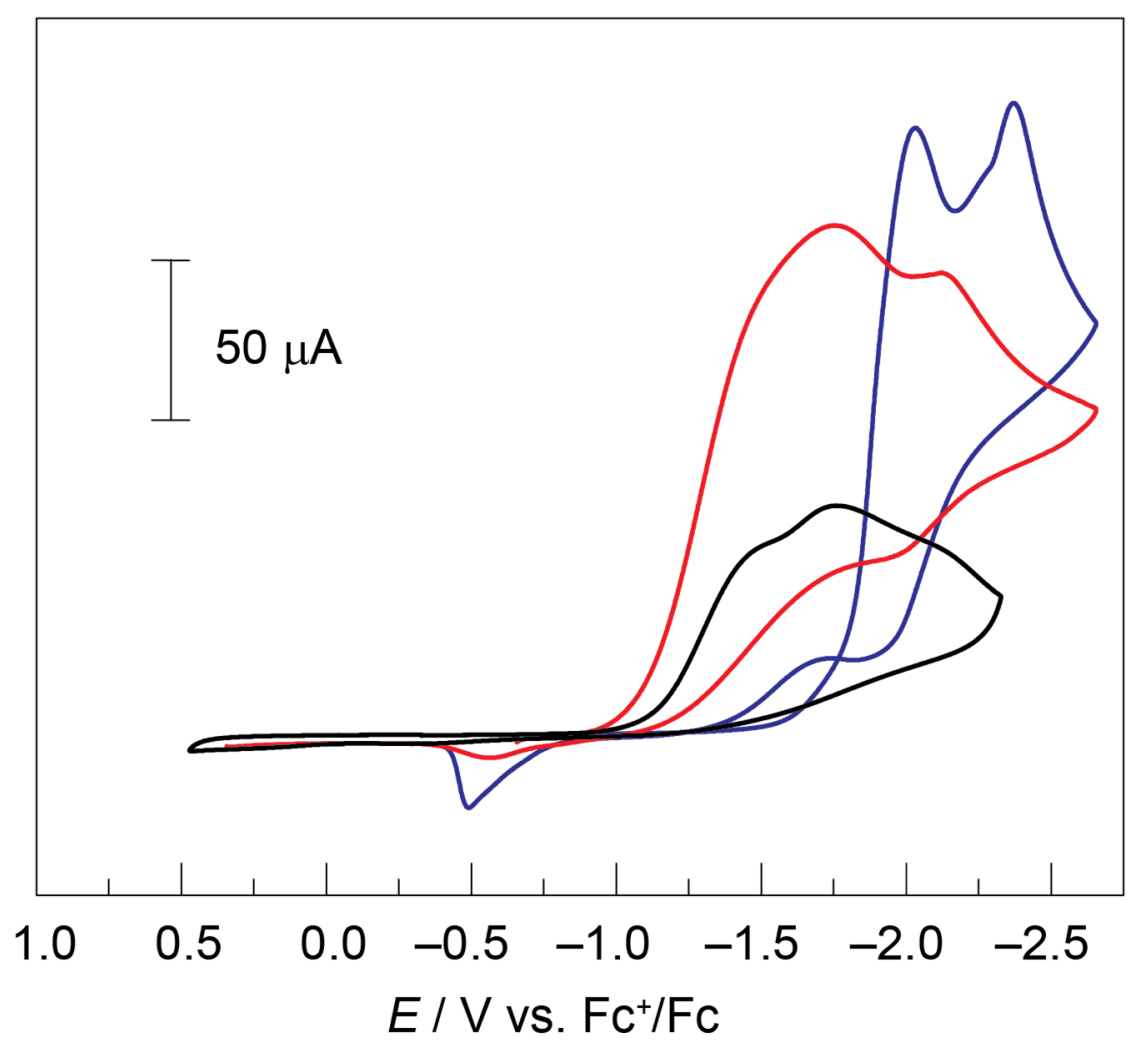

Figure S19. Blue trace (-): $\mathrm{CV}$ of $0.5 \mathrm{mM} \mathrm{Ni}\left(\mathrm{ClO}_{4}\right)_{2} \cdot 6 \mathrm{H}_{2} \mathrm{O}$ in $\mathrm{CH}_{3} \mathrm{CN}\left(0.1 \mathrm{M} \mathrm{TBAPF}_{6}\right)$ at a scan rate of $0.1 \mathrm{~V} \mathrm{~s}^{-1}$ using a glassy carbon working electrode (3.0 mm diameter) in the presence of $20 \mathrm{mM}$ tosic acid. Red trace (-): CV taken using the same working electrode in fresh $\mathrm{CH}_{3} \mathrm{CN} /$ electrolyte solution containing only $20 \mathrm{mM}$ tosic acid after a potential of $-1.7 \mathrm{~V}$ vs. $\mathrm{Fc}^{+} / \mathrm{Fc}$ was held in the solution containing $0.5 \mathrm{mM} \mathrm{Ni}\left(\mathrm{ClO}_{4}\right)_{2} \cdot 6 \mathrm{H}_{2} \mathrm{O}$ and $20 \mathrm{mM}$ tosic acid for 3 min. Black trace (-): CV of a freshly polished glassy carbon electrode in the $\mathrm{CH}_{3} \mathrm{CN} /$ electrolyte solution containing only $20 \mathrm{mM}$ tosic acid (no $\mathrm{Ni}\left(\mathrm{ClO}_{4}\right)_{2} \cdot 6 \mathrm{H}_{2} \mathrm{O}$ in solution). 


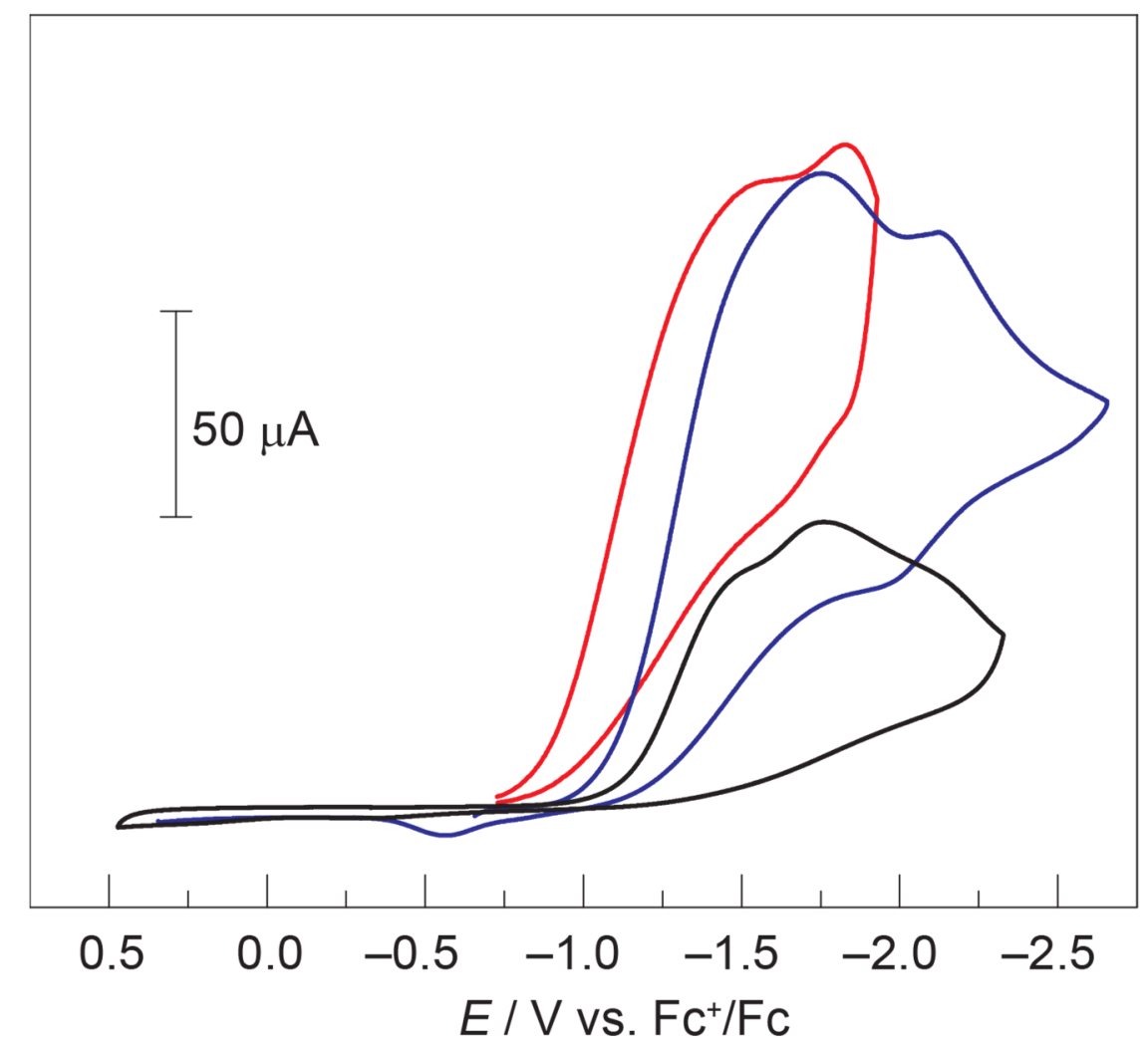

Figure S20. Blue trace (-): CV taken using the same working electrode in fresh $\mathrm{CH}_{3} \mathrm{CN} /$ electrolyte solution containing only $20 \mathrm{mM}$ tosic acid after a potential of $-1.7 \mathrm{~V}$ vs. $\mathrm{Fc}^{+} / \mathrm{Fc}$ was held in the solution containing $0.5 \mathrm{mM} \mathrm{Ni}\left(\mathrm{ClO}_{4}\right)_{2} \cdot 6 \mathrm{H}_{2} \mathrm{O}$ and $20 \mathrm{mM}$ tosic acid for $3 \mathrm{mi}$. Red trace (-): CV taken using the same working electrode in fresh $\mathrm{CH}_{3} \mathrm{CN} /$ electrolyte solution containing only $20 \mathrm{mM}$ tosic acid after a potential of $-1.7 \mathrm{~V}$ vs. $\mathrm{Fc}^{+} / \mathrm{Fc}$ was held in the solution containing $0.5 \mathrm{mM} \mathrm{Ni}$-iBC and $20 \mathrm{mM}$ tosic acid for $3 \mathrm{~min}$. Black trace (-): CV of a freshly polished glassy carbon electrode in the $\mathrm{CH}_{3} \mathrm{CN}$ /electrolyte solution containing only $20 \mathrm{mM}$ tosic acid. 


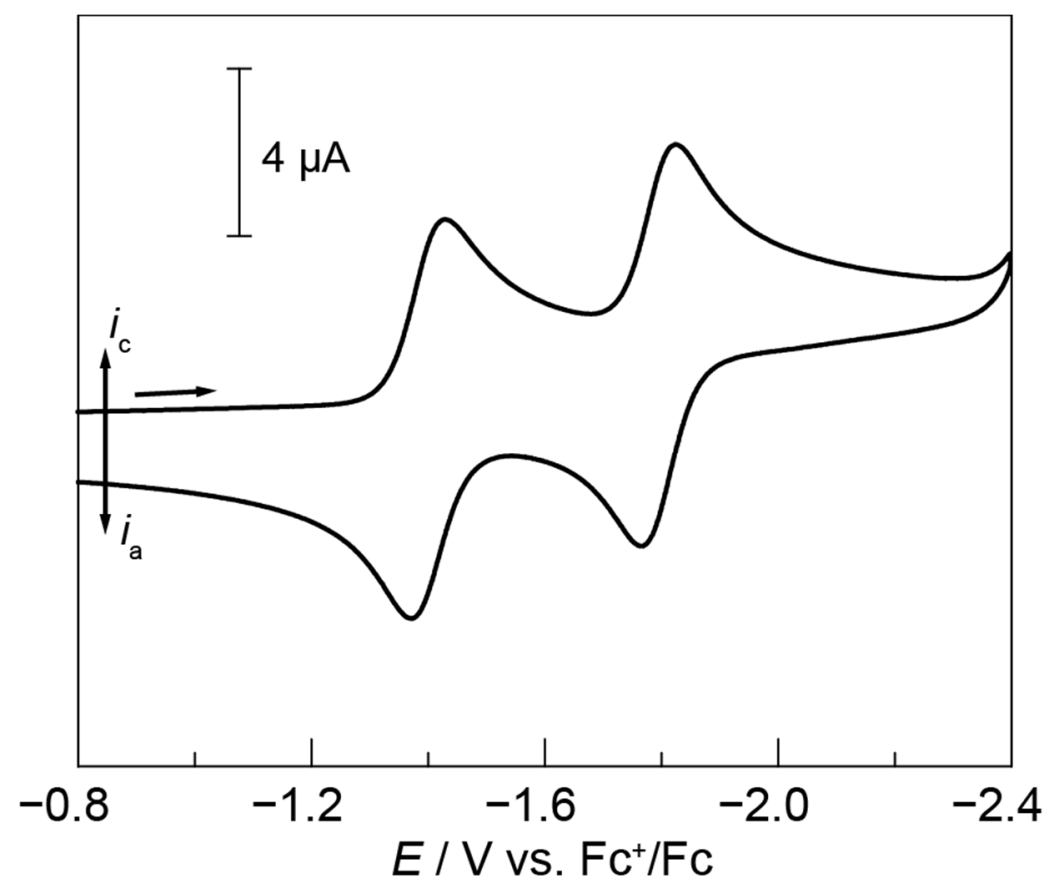

Figure S21. $\mathrm{CV}$ of $\mathbf{Z n}-\mathbf{P}$ in $\mathrm{CH}_{3} \mathrm{CN}\left(0.1 \mathrm{M} \mathrm{TBAPF}_{6}\right)$ at a scan rate of $0.1 \mathrm{~V} \mathrm{~s}^{-1}$. 